\title{
Urban ponds as a potential risk in the transmission of parasites
}

\author{
Stella Maris MARTÍN ${ }^{1,2, *}$, Verónica NÚÑEZ ${ }^{1,2}$, Diego E. GUTIÉRREZ GREGORIC ${ }^{1,3}$ \\ \& Alejandra RUMI ${ }^{1,3}$
}

\begin{abstract}
${ }^{1}$ División Zoología Invertebrados, Museo de La Plata, Facultad de Ciencias Naturales y Museo, Universidad Nacional de La Plata. Paseo del Bosque S/N, B1900FWA, La Plata, Buenos Aires, Argentina. ${ }^{2}$ Comisión de Investigaciones Científicas de la provincia de Buenos Aires (CIC). ${ }^{3}$ Consejo Nacional de Investigaciones Científicas y Técnicas (CONICET) La Plata, Buenos Aires, Argentina. *Corresponding author. Email: smartin@fcnym.unlp.edu.ar
\end{abstract}

\begin{abstract}
We studied freshwater snails inhabiting an urban pond in an enclosed private community from the northern Province of Buenos Aires, Argentina for a year and monitored individuals in order to observe parasite emergence. Specimens of the predominant snail species were measured and analyzed histologically to examine possible larval effects on the gonadal tissue causing alterations in the developmental stages of the gonads and the degree of parasite prevalence per age, sex, and host size calculated. Four species of snails were registered: Pomacea canaliculata, Physa acuta, Biomphalaria peregrina and Heleobia parchappii. The last of these was the most abundant, whose breeding season was in the spring. The parasitized snails exhibited a greater average length than those free of parasites. The larval prevalence increased with host length, becoming the highest in post-reproductive stage, but was not different between the sexes. Among the emerged cercariae, we noted a marked predominance of the family Notocotylidae.
\end{abstract}

Key words: cercariae, parasite prevalence, snails, urban ponds

Resumen: Los estanques urbanos como un riesgo potencial en la transmisión de parásitos. Se estudiaron durante un año los gasterópodos de agua dulce que habitan en un estanque urbano en una comunidad privada cerrada del nordeste de la provincia de Buenos Aires, Argentina. Se monitorearon individuos para observar la emergencia de parásitos. Los especímenes de las especies de caracoles predominantes se midieron y se analizaron histológicamente para examinar los posibles efectos de larvas en el tejido gonadal, provocando alteraciones en las etapas de desarrollo de las gónadas y el grado de prevalencia de parásitos por edad, sexo, y el tamaño del hospedador calculado. Se registraron cuatro especies de gasterópodos: Pomacea canaliculata, Physa acuta, Biomphalaria peregrina y Heleobia parchappii. La última de estas fue más abundante, cuya época de oviposición fue en primavera. Los caracoles parasitados exhibieron una longitud promedio mayor que aquellos libres de parásitos. La prevalencia de larvas aumentó con la longitud del hospedador, llegando a ser la más alta en individuos en etapa postreproductiva, pero no fue diferente entre los sexos. Entre las cercarias emergentes, notamos un marcado predominio de la familia Notocotylidae

Palabras clave: cercarias, prevalencia parasitaria, gasterópodos, lagunas urbanas.

\section{INTRODUCTION}

In recent years in Argentina a number of enclosed private communities have developed near to zones of recurrent flooding, converting the quarries originally produced in the elevation of lands and construction of those settlements into urban-associated ponds as an attractive alternative form of landscaping. The resulting housing communities surround those artificial ponds, which are used for common recreational purposes and have private and exclusive access to the residents (Ríos \& Pírez, 2008; Ríos, 2009).
One of the biocenoses consolidating in these new environments is of the freshwater gastropods, a group which usually acts as an intermediate host of digeneans, causing human parasitisms and other zoonoses. Among the gastropod species of relevance to health-related issues in Argentina, species of Biomphalaria can be cited that act as hosts of schistosomiasis throughout all of South America, and more specifically, species of Lymnaeidae, the vectors of fascioliasis. In addition, species of the family Physidae and of the genera Chilina, Biomphalaria, and Heleobia are intermediate hosts of trematodes of the fam- 
ily Schistosomatidae, whose cercariae can cause human dermatitis (Rumi et al., 2008; Rumi \& Núñez, 2013).

Parasite recruitment and turnover are affected by a range of influences both external and internal to the host. Free-living parasitic stages are directly affected by external environmental conditions; while host behaviour, age, and sex are parameters that may influence the infrapopulation biology of parasitic organisms (Esch \& Fernández, 1993). In the example of an intermediate snail host, the rate of establishment of new infection within a local population depends on the susceptibility of the individual snails that are the constituents. The susceptibility of hosts may vary with the species or the genetic strain of the parasite along with specific host characteristics such as age, sex, and genotype (Sousa, 1990). For guilds of larval trematods in snail hosts, a high overall prevalence provides a necessary condition for an interactive assemblage. If dominant species have a sufficiently high relative prevalence, they can exert a competitive pressure that is sufficient to alter the abundance of the subordinate species (Kuris, 1990).

Despite the recreational use of these new kinds of aquatic environments, no studies as of yet exist analysing the possible parasites that can develop in such water bodies. Therefore, the objective of the study reported here was to determine the taxocenosis of freshwater gastropods from such ponds and evaluate the resulting parasitic status.

\section{MATERIALS AND METHODS}

\section{Study site}

The gastropods were collected in 12 samplings from May 2005 through May 2006 in an anthropically impacted environment within the region of the Tigre River in the Province of Buenos Aires, Argentina ( $34^{\circ} 26^{\prime} \mathrm{S}, 58^{\circ} 37^{\prime} \mathrm{W}$ ). The sampling was performed with a sieve (area, 0.025 $\mathrm{m}^{2}$ ) of diameter $18 \mathrm{~cm}$ and grid pore size $0.14 \mathrm{~mm}$ (Gutiérrez Gregoric \& Núñez, 2010). In the laboratory, subsamples of the predominant species were separated for histological studies.

This pond has a surface of 60 hectares, with a substratum characterized by clay and sand, and it is surrounded by a prolific urbanization (family dwellings) over an area of 256 hectares. This project has been carried out at lowlands and subject to flooding which have been raised through the construction of a pond and a reforestation of the area. In this environment, there can be observed diverse hydrophilic plants: floating macrophytes clearly free, rooted, totally submerged, upright (ex. Eichhornia crassipes, Ludwigia peploides, Miriophylum aquaticum, Schoenoplectus californicus (Lahitte \& Hurrell, 1996). The continuous extraction of this vegetation encourages the growth of the algae community that decreases the clarity of the lagoon, and eventually causes explosions, some of them are the cause of human dermatitis, especially cyanophyceae Anabaena lemmermani (Obs. personal). On the other hand, in this pond only water sports that do not contaminate may be practiced, such as windsurf, rowing and swimming.

\section{Gastropod community}

The population density of the snail species was estimated as the number of specimens per sieve surface $\left(0.25 \mathrm{~m}^{2}\right)$. After measuring the total length of individuals of the predominant species on site with a caliper of precision $0.01 \mathrm{~mm}$, those data were sorted into the various size classes at 0.25 -mm intervals for analysis of the age structures and recruitment periods.

\section{Assessment of parasite emergence}

Snails were housed individually in containers with nonchlorinated water and exposed to the warm light from lamps. Thereafter the specimens were monitored for three days by stereomicroscopy, at the end of which time all the snails were dissected in order to screen for the possible presence of nonemerged larval stages. The prevalence of parasitism, expressed as the percentage of snails from which cercariae emerged or with pre-emerged larvae among the total exposed to these laboratory conditions, was calculated for each of the species collected. We classified the cercariae down to the family level following the criteria of Ostrowski de Núñez (1992).

\section{Histological studies}

During the 8 months of the experiment, subsamples of the predominant species were examined histologically. More than 400 specimens were sexed and measured under a stereomicroscope equipped with a micrometer-containing ocular, then relaxed in water laced with menthol tablets for about $12 \mathrm{~h}$ before fixation for $48 \mathrm{~h}$ in an alcohol-based Bouin's solution to decalcify the shells. The visceral mass including those organs was treated with Paraplax in order to make $10-\mu \mathrm{m}$ histological sections. The samples were next stained with hematoxylin-eosin and photographed with an Olympus camera. We examined 
the histologic stages of gonadal development in relation to the presence of the larvae and in that manner monitored the effects that parasitosis had on the differentiation of the gonadal tissue. On the basis of those data, we calculated the parasite prevalence (percentage of parasitized snails among the total dissected) with respect to sex and body size. Three categories of body size were recognized: juveniles, of length less than 4 $\mathrm{mm}$; adults, of length between 4 and $6 \mathrm{~mm}$; and post reproductive snails of length greater than 6 mm (Martín 2008, Martín \& Díaz 2016). The relationship between the size of parasitized snails and the size of those which do not have parasites, as well as the sex and the time of the year have been tested through the ANOVA analysis.

\section{RESULTS}

During the sampling period, a total of four species of gastropods was registered in the study area: Physa acuta Draparnaud, 1805, Heleobia parchappii (d'Orbigny, 1835), Biomphalaria peregrina (d'Orbigny, 1835), and Pomacea canaliculata (Lammarck, 1822). The most abundant species was $H$. parchappii, it having been registered at the highest density in all the months and having passed through a peak in April 2006 (Table 1).

No parasites were present in 591 specimens of $P$. acuta exposed to light and heat in the laboratory, as of May 2006, the last month of the experiment; while only one snail was parasitized out of 204 specimens of $P$. canaliculata, but they were with digenean larvae that could not be further characterized. Of the total of 154 specimens of $B$. peregrina analyzed during the study period, eight were parasitized. From those eight snails, four specimens released xiphidiocercariae (one snail in May 2005, one in January 2006, and two in March 2006), three were parasitized by members of the Notocotylidae family (March 2006), and one contained Petasiger sp. (May 2005).

In contrast, among 2,276 specimens of $H$. parchappii exposed to light and heat under the same conditions in the laboratory, some 1,008 were found parasitized. Higher values of parasitic prevalence occurred in July, exceeding 55\% (Table 2). Cercariae emerged that belonged to seven known families (plus one not identified), while sporocysts and rediae were found in the visceral masses of the specimens that were dissected. Among the emerged cercariae, we noted a marked predominance of members of the Notocotylidae (Table 2).
Among the total of 1,970 specimens of $H$. parchappii that were measured, the maximum shell size recorded was $8.16 \mathrm{~mm}$, while the minimum was $1.06 \mathrm{~mm}$. The average length of shells that were obtained from monthly sampling had lower values during spring (October to December) that match with the main recruitment of the juveniles (Fig. 1).

Upon histological analysis, the parasitized snails exhibited a significantly higher average length than that of the parasite-free individuals throughout the entire year $\left(\mathrm{F}_{0.05(1,490)}=79.6 ; p<\right.$ 0,0001 Fig. 2). Moreover, the prevalence of parasitism by Digenea in $H$. parchappii increased roughly in proportion to the length of the snail (Fig. 3). This progressive increment plateaued at $100 \%$ parasitization for individuals of body lengths greater than $7.5 \mathrm{~mm}$ in the postreproductive stage (Fig. 3), which developmental phase was registered at the highest proportion in the winter month of August (Fig. 4). In contrast, the proportion of juveniles peaked during the spring, in the months of October and November, as well as during the summer, in January.

Of the total number of specimens of $H$. parchappii analyzed $(\mathrm{N}=486)$, almost $64 \%$ were females. This female predominance was observed for six out of the eight months monitored during the year (Fig. 5), there are no significant differences in the prevalence values among sexes, $\left(\mathrm{F}_{0.05(1,141)}=0.6 ; p=0.42\right)$ throughout the year with all the months taken together. The highest percentage of the snails parasitized between both sexes (at 58.6\%) was recorded in August, followed by the months of May in both years (Fig. 5, gray curve). Significant differences among parasitized snails' length and the collection date have been verified $\left(\mathrm{F}_{0.05(7,135)}=48.34 ; p<0,0001\right)$

Peak levels of parasitism were recorded in adult females (Fig. 6A) - as evidenced by gonadal follicles in a state of maturation or the evacuation of gametes-in the two May samples, as well as in the juveniles in January. The gonadal follicles of the adult males (Fig. 6B) were $100 \%$ parasitized by digenean larvae in January and May of 2006, whereas during 2005 the parasitization never reached a level of even $75 \%$. We observed that the female follicles in a complete state of maturation contained abundant larvae that produced an emptying of the gonadal follicles along with a disordering of the acini of the digestive gland (Fig. 6C, D and F). In some instances, the cell types-e. g., oogoniawere seen to be partially deformed (Fig. 6E). 
Table 1. Density (ind $\left./ \mathrm{m}^{2}\right)$ of snails species in each sampling date

\begin{tabular}{lcccc}
\hline Date & P. acuta & H. parchappii & B. peregina & P. canaliculata \\
\hline may-05 & 190 & 642 & 14 & 10 \\
jun-05 & 136 & 706 & 0 & 0 \\
jul-05 & 86 & 711 & 0 & 7 \\
aug-05 & 80 & 385 & 0 & 1 \\
sep-05 & 245 & 427 & 5 & 8 \\
oct-05 & 174 & 1303 & 6 & 9 \\
nov-05 & 118 & 1657 & 20 & 2 \\
dec-05 & 136 & 1052 & 18 & 46 \\
jan-06 & 46 & 890 & 19 & 36 \\
mar-06 & 100 & 1611 & 85 & 136 \\
apr-06 & 41 & 2964 & 57 & 124 \\
may-06 & 18 & 2370 & 133 & 139 \\
\hline
\end{tabular}

Table 2. Prevalence of Digenea families in Heleobia parchappii specimens exposed to light and heat.
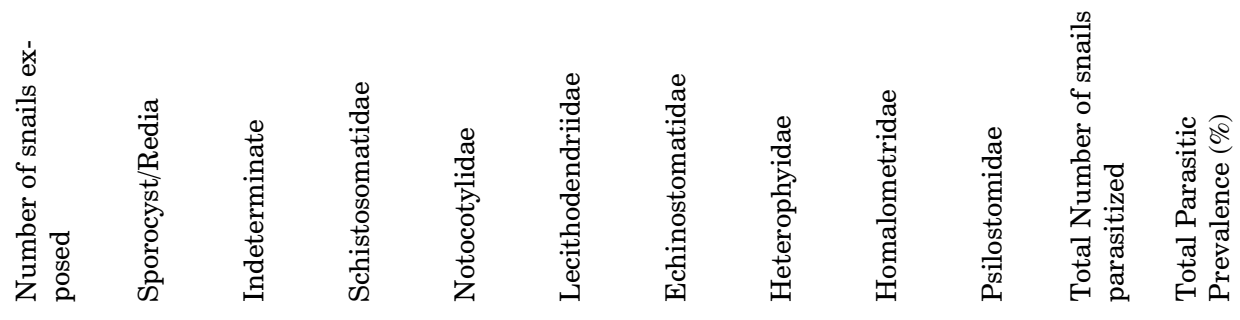

\begin{tabular}{lcccccccccccc}
\hline May 05 & 175 & 4.0 & 0.6 & 0.0 & 43.4 & 1.1 & 0.6 & 0.0 & 0.6 & 0.0 & 88 & 50.3 \\
Jun 05 & 167 & 3.6 & 0.0 & 0.0 & 41.3 & 1.8 & 0.0 & 0.0 & 3.6 & 0.0 & 84 & 50.3 \\
Jul 05 & 189 & 1.6 & 0.0 & 0.0 & 48.1 & 2.6 & 0.0 & 0.5 & 2.6 & 0.0 & 105 & 55.6 \\
Aug 05 & 194 & 1.0 & 0.0 & 0.5 & 40.7 & 1.0 & 0.0 & 0.5 & 2.6 & 2.6 & 95 & 49.0 \\
Sep 05 & 196 & 2.0 & 0.0 & 0.5 & 39.3 & 1.0 & 0.0 & 0.5 & 1.0 & 1.0 & 89 & 45.4 \\
Oct 05 & 192 & 0.5 & 0.0 & 0.0 & 20.3 & 0.0 & 0.0 & 0.0 & 0.5 & 0.0 & 41 & 21.4 \\
Nov 05 & 191 & 4.7 & 0.0 & 0.0 & 35.1 & 0.0 & 0.0 & 0.0 & 1.0 & 1.0 & 80 & 41.9 \\
Dec 05 & 170 & 2.9 & 0.0 & 0.0 & 29.4 & 0.6 & 0.0 & 1.2 & 2.4 & 1.8 & 65 & 38.2 \\
Jan 06 & 201 & 4.5 & 0.0 & 0.0 & 32.3 & 1.5 & 1.0 & 1.5 & 1.0 & 2.5 & 89 & 44.3 \\
Mar 06 & 170 & 1.8 & 1.2 & 0.6 & 31.8 & 0.0 & 1.2 & 0.0 & 0.6 & 0.6 & 64 & 37.6 \\
Apr 06 & 180 & 4.4 & 0.6 & 0.6 & 28.3 & 0.0 & 0.0 & 2.2 & 0.0 & 4.4 & 73 & 40.6 \\
May 06 & 251 & 4.4 & 2.0 & 2.0 & 33.9 & 0.0 & 0.0 & 0.4 & 8.4 & 2.8 & 135 & 53.8 \\
& 2276 & 6.7 & 0.9 & 0.9 & 79.7 & 1.8 & 0.5 & 1.3 & 5.0 & 3.3 & 1008 & 44.3 \\
\hline
\end{tabular}




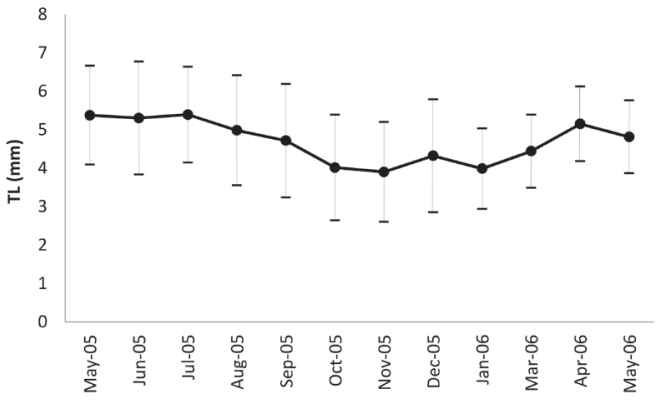

Fig. 1. Percent shell-size of Heleobia parchapii (ordinate) as measured during the indicated months within the study period. Dots: mean; -: SD.

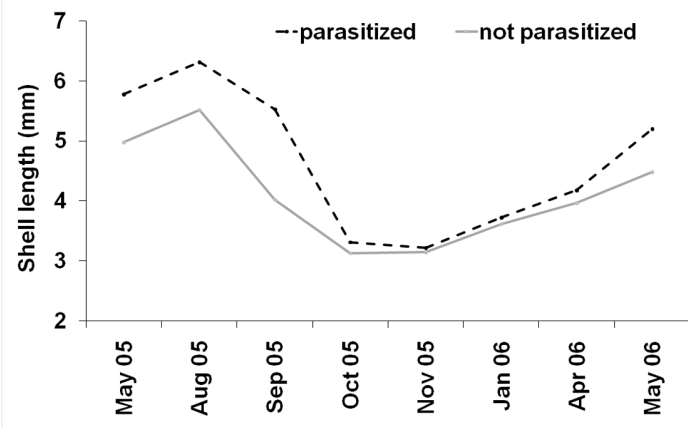

Fig. 2. Average shell length of the specimens of Heleobia parchapii studied by histological analysis parasitized by Digenea (black broken line) and not parasitized (gray line). In the figure, the shell length in $\mathrm{mm}$ is plotted on the ordinate or each of the months during the study period indicated on the abscissa.

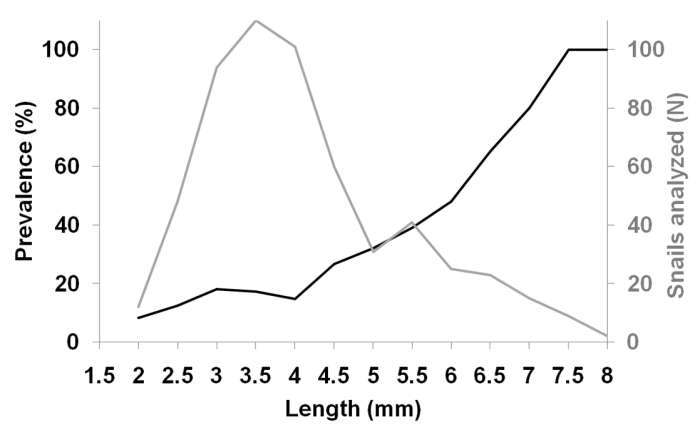

Fig. 3. Prevalence of Digenea parasitism in the host Heleobia parchappii as evidenced by histological analysis. Abscissa, length of $H$. parchappii (mm); ordinate, percentage of snails parasitized (black line) of a given length among those analyzed ( $\mathrm{N}$, gray line)

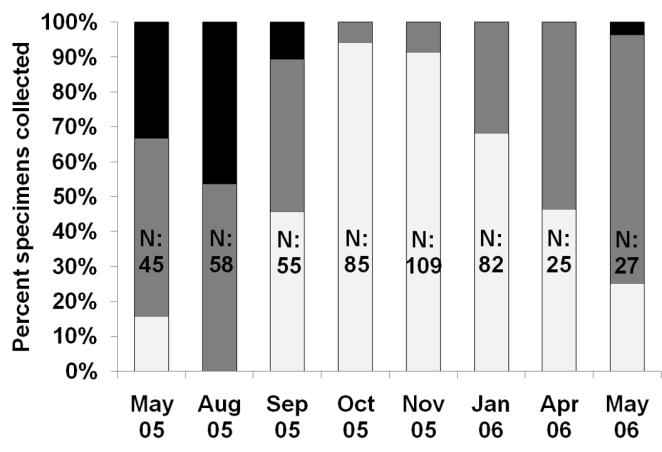

Fig. 4. Fractional-length class indicated by bar shading, expressed as a percent (ordinate), obtained upon histological analysis of Heleobia parchappii on each monthly sampling date (abscissa). The total height of the bars represents $100 \%$, while the fraction of each bar in a given shade denotes the proportion of that developmental stage within the total number of individuals analyzed. Key to bar-zone shades: postreproductive snails, upper black; adults, middle gray; juveniles, lower white. N, the number of snails in each sample

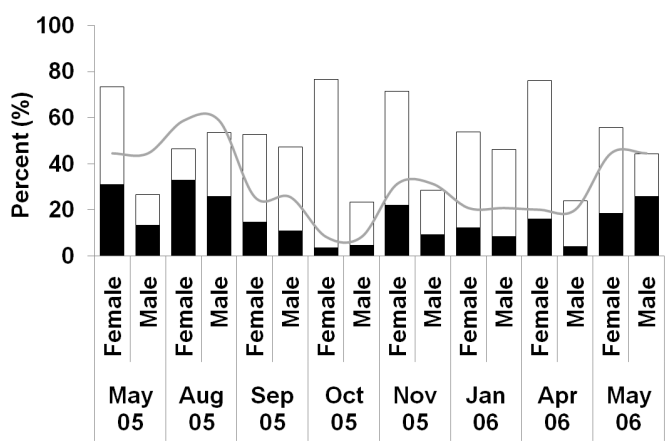

Fig. 5. Proportion of male and female Heleobia parchappii parasitized and nonparasitized by Digenea as determined by histologic analysis throughout the year-long sampling period. For each monthly sampling indicated on the abscissa, the percentage of: females (left bar) and males (right bar) either parasitized (black lower bar zone) or nonparasitized (white upper bar zone) is plotted as a percent (ordinate). The gray curve denotes the total percent of snails of both sexes parasitized. 


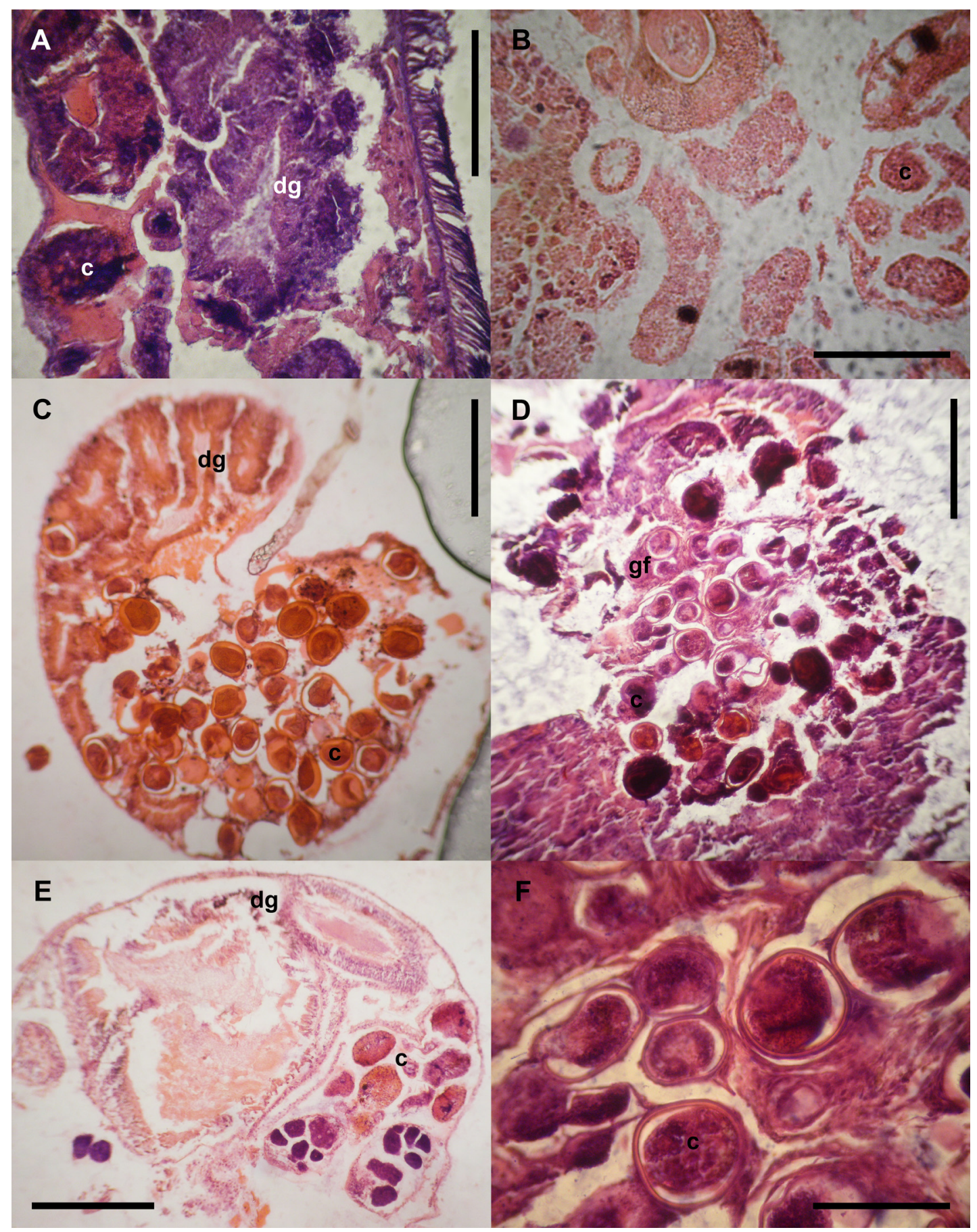

Fig. 6. Photographs of hematoxylin-eosin-stained $10-\mu \mathrm{m}$ sections illustrating cercariae infecting Heleobia parchappii females (A 400X) and a male. (B 400X), fully developed male gametes lying between the cercariae and the digestive gland (C and D- 100X), female gonads being almost completely absent (E-100X), and cercariae infecting female-gonad maturation. (F 400X). 


\section{DISCUSSION}

Heleobia parchappii is distributed in lentic and lotic environments in the pampas region of Argentina and exhibits a seasonal cycle of reproduction; but in contrast to those specimens observed by De Francesco \& Isla (2004a) and Merlo et al. (2016), the population investigated here did not show any particular recruitment during the fall or winter. Yet, it showed a main recruitment during spring (October to December) and a smaller one during summer. Other species of Heleobia in sites related to the Río de la Plata river and the province of Buenos Aires also show annual cycles with two yearly recruitmens: some during spring like in this study $(H$. conexa - De Francesco \& Isla, 2004b), while others during winter and summer $(H$. australis - De Francesco \& Isla, 2004b; Carcedo \& Fiori, 2012; H. piscium (Martín, 2008) and H. parchappii (De Francesco \& Isla, 2004a), as both species present only one reproductive period during summer or spring, respectively. On the other hand, Cazzaniga (1982) studies southern populations in misohalines and oligohalines environments of $H$. parchappii at the Rio Colorado region of the province of Buenos Aires, in which he discovered an unstable size structure and a high number of juveniles. This author studied three key moments of the life cycle of a snail: one during winter (mainly adults and a low proportion in juveniles), other during summer (in which a population replacement took place), and the third during autumn (subadult juveniles, i.e. sexually active).

Our results evidenced temporary variations in the parasite prevalence, but contrary to the observations of Merlo et al. (2016), the highest values were recorded in the colder months. In those months where we registered a greater number of post-reproductive stage individuals, we encountered the highest prevalence; whereas in the months with a predominance of juveniles, the prevalence was lower. This may be due to the fact that higher size/length snails tend to be older, and the higher exposure time can be the reason for the positive correlations with the size of the host (Castro et al. 2006; Zimmermann et al. 2016). During spring, as there are a higher number of juveniles, the parasite prevalence was lower.

The annual mean parasitism prevalence of $30 \%$, at peaks of $59 \%$, with $H$. parchappii observed in this work is substantially greater than the figures registered with $H$. australis by Castro et al. (2006) and Etchegoin (2001) of 22.6\% and $10.4 \%$, respectively. Studies on freshwater pulmonates have demonstrated that parasitic infection can reduce or even completely inhibit host reproduction (Minchella et al. 1985). Those observations coincide with the report of Sorensen \& Minchella (2001) demonstrating a parasiteinduced host-tissue damage that resulted in castration, gigantism, or dwarfism. In the present study, the individuals in the reproductive stage suffered parasitic alterations involving the total or partial destruction of the gonadal follicles, thus preventing normal gamete development. It has been demonstrated that in male $H$. parchappii, the infestation of certain digenea may produce a decrease in the size of the penis (Merlo et al. 2017). These alterations in $H$. parchappii had also been observed in Biomphalaria glabrata (Say, 1818), Bradybaena similaris (Férussac, 1821), Chilina dombeyana (Bruguière, 1789), and Hydrobia ventrosa (Montagu, 1803; Théron \& Gérard, 1994; Paschoal \& Amato, 1996; Olmos \& George-Nascimento, 1997; Kube et al. 2006; Valdovinos \& Balboa 2008, Horak \& Kolarova, 2011).

In addition to parasitic castration, the larvae can produce modifications in the digestive gland of a gastropod host (in both adults and juveniles), as reported by Rees (1936) in Littorina littorea (Linné, 1758) and L. saxatilis (Olivi, 1792), and Sivajothi \& Sudhakara Reddy (2018) in Biomphalaria glabrata. In the present work, we observed that the digestive acini underwent a markedly pronounced disordering to the point that, in certain specimens, a nearly complete absence of secretory and excretory cells from the interior of the follicles became evident.

Heleobia parchappii is a host for at least 24 species of digeneans, including some that produce cercariae causing human dermatitis (Szidat,1958; Ostrowski de Núñez, 1978; Merlo et al. 2014). The number of digenean-larval families that emerged from this species in the present investigation was considerably lower than that identified by Alda \& Martorelli (2014) in $H$. australis and by Merlo et al. (2014, unpublished data) in $H$. parchappii and $H$. australis in freshwater environments and estuaries of the Buenos Aires province.

\section{CONCLUSIONS}

In the ponds within the enclosed private periurban communities that we investigated, $H$. parchappii was found to be the predominant species throughout the year, evidencing a pro- 
gressively rapid and efficient adaptation to those newly formed environments. This predominance in those ponds enabled that species to be a more stable resource as a host for digenean parasitism. Biomphalaria peregrina and P. canaliculata evidenced a slight increase in density during the last months of the sampling, and only then did those species begin to act as hosts for digenean larvae. In contrast, since $P$. acuta is an exotic species, those snails had not yet become adequate hosts for the digenean parasites present in those environments.

Digenean infections of molluscs can result in a reduction or complete inhibition of a snail's egg production or in a significant increase in egg-laying during the prepatent period (time between parasite exposure and the first shedding of cercariae) (Minchella, 1985). Hence, the differences in the recruitment periods observed in $H$. parchappii could result from a strategy by the snail to prevent the negative effects on reproductive success caused by the digenean parasitism.

The predominance of Notocotylidae may be due to the fact that together with Schistosomatidae they are the only families present in this environment that do not require a second intermediate host. Notocotylidae species have a twohost life cycle with cercariae encysting in the open. Even though the majority of the species in this family mentioned in Argentina are parasitized of birds (Fernandes et al. 2015), we may assume that, in this particular case, it is of species parasites of aquatic rodents which constitute in autogenic species (Esch \& Fernandez, 1994). The entire life cycle of these parasites is completed within the confines of a freshwater habitat and both intermediate and definitive hosts reside in the habitat permanently. An important implication in this concept is that autogenic parasites are permanent residents in the habitat and, therefore, have the potential of providing a continuous source of eggs for transmission. Besides, in Notocotylidae eggs are the infective stage for the molluscan host, they usually remain infective for long periods of time, certainly longer than the short-lived, free-swimming miracidia.

It is highly likely that the Schistosomatidae species present in this environment are parasites of birds, since species of this family have not been cited parasitizing mammals in Argentina (Fernandes et al. 2015). Therefore, these trematodes species are considered allogenic parasites, since they complete their life cycles in hosts which are temporary, or ephemeral, visitors to the habitat, and thus they provide a discontinuous source of infective agents to the habitat (Esch \& Fernandez, 1994).The infective stages of these species are short-lived free-swimming miracidia.

On the other hand, the almost permanent presence of Homalometridae along the year, even in low prevalence, may also be due to they are autogenic species, as they are parasites of fishes.

Although no species representing a high risk for the surrounding human population were recorded, cercariae of the Schistosomatidae family were registered, which can cause human dermatitis. So that, apart from the presence of Cyanophyceae, these parasites may be other cause for the cases of dermatitis detected in the environment (Echenique \& González, 1998; Res MSN 1949, 2016).

In agreement with the observations made by Zimmermann et al. (2014), we may say that the anthropogenic alternations (construction of houses around it) connected to the changes in the original environment may lead to changes in the microhabitat, and hence have influence in the population of intermediate hosts (snails), and in digenetic parasites that infect definitive hosts (fishes, aquatic mammals).

Thus, the presence of those gastropods might represent a possible risk to human health because of the recreational use of these ponds.

\section{ACKNOWLEDGEMENTS}

Thanks to an anonymous reviewer whose comments improved this manuscript. This study was supported by the Subsidio Automático of the Facultad de Ciencias Naturales y Museo, La Plata $\mathrm{N}^{\circ}$ 727. Dr. Donald F. Haggerty, a retired academic career investigator and native English speaker, translated the manuscript from the original Spanish and edited the final version.

\section{REFERENCES}

Alda, P. \& S. Martorelli. 2014. Larval trematodes infecting the South-American intertidal mud snail Heleobia australis (Rissooidea: Cochliopidae). Acta Parasitology 59: 50-67.

Castro, O, D. Carnevia, A. Perretta \& J.M. Venzal. 2006. Comunidad componente de tremátodos larvales de Heleobia australis (Mollusca, Cochliopidae) en la costa uruguaya del Río de la Plata. In: MENAFRA R ET AL. (Eds), Bases para la conservación y el manejo de la costa uruguaya. Vida Silvestre Uruguay, Montevideo, Uruguay, p. 421-425.

Cazzaniga, N.J. 1982. Notas sobre hidróbidos argentinos. 5. Conquiliometría de Littoridina parchappii (D’Orbigny, 1835) (Gastropoda Rissoidea) referida a su ciclo de vida en poblaciones australes. Iherin- 
gia Serie Zoologìa. Porto Alegre 61:97-118

De Francesco, C.G \& F.I. Isla. 2004a. Reproductive period and growth rate of the freshwater snail $\mathrm{He}$ leobia parchappii (d'Orbigny, 1835) (Gastropoda: Rissooidea) in a shallow brackish habitat (Buenos Aires Province, Argentina). Malacologia 45: 443450.

De Francesco, C.G., \& F.I. Isla. 2004b. The life cycle and growth of Heleobia australis (D'Orbigny, 1835) and H. conexa (Gaillard, 1974)(Gastropoda: Rissooidea) in Mar Chiquita coastal lagoon (Argentina). Journal of Molluscan Studies 70, 173-178.

Departamento de Salud Ambiental Dirección Nacional de determinantes de la salud Subsecretaría de Relaciones Institucionales Secretaría de Relaciones Nacionales e Internacionales Ministerio de Salud de la Nación. Exposición a Cianobacterias/ Cianotoxinas en agua y efectos en salud.Guía para el Equipo de SaludPp:1-17. http://www.msal.gob. ar/politicassocioambientales/images/stories/descargas/recursos/resol_msn_1949-16_2.pdf

Echenique, R. \& D. González. 1998. Las Cianofítas. Microalgascausantes de Toxicidad. Revista Museo. Fundación Museo de La Plata. "Francisco P. Moreno". № 12 , pp: $78-80$

Esch, G.W. \& J.C. Fernández. 1993. A functional biology of parasitism, Chapman \& Hall, London. 289 p.

Esch, G.W. \& J.C. Fernández.1994. Snail-trematode interactions and parasite community dynamics in aquatic systems: a review. American Midland $\mathrm{Na}$ turalist 131:209-237.

Etchegoin, J. 2001. Dinámica de los sistemas parasitarios. In: IRIBARNE O (Ed) Reserva de Biosfera Mar Chiquita: Características físicas, biológicas y ecológicas. Editorial Martín, Mar del Plata, Argentina, p. 171-185.

Fernandes, B.M.M., M.C.N. Justo, M.Q. Cárdenas \& S.C. Cohen. 2015. South american trematodes parasites of birds and mammals Río de Janeiro: Biblioteca de Ciências Biomédicas. ICICT. FiocruzRJ. 516 pp.

Gutiérrez Gregoric, D.E \& V. Núñez. 2010. Método de colección de moluscos: gasterópodos continentales. División Zoología Invertebrados, Museo de La Plata. FCNyM. UNLP, La Plata, Argentina, Serie Didáctica 1: 1-9.

Horak, P. \& L. Kolarova. 2011. Snails, waterfowl and cercarial dermatitis. Freshwater Biology 56, 779790.

Kube, S.,J. Kube. \& A. Bick. 2006. A loss fecundity in a population of mudsnails Hydrobia ventrosa caused by larval trematodes does not measurably affect host population equilibrium level. Parasitology 132: 725-732.

Kuris, A.M. 1990. Guild structure of larval trematodes in molluscan hosts: Prevalence, dominance and significance in competition. In: ESCH GW ET AL. (Eds), Parasite communities: Patterns and processes. Chapman and Hall, London, U.K., p. 69-100.

Martín, S.M. 2008. Individual growth of Heleobia pisci$u m$ in natural populations (Gastropoda: Cochliopidae) from the Multiple Use Natural Reserve Isla
Martin Garcia, Buenos Aires, Argentina. Brazilian Journal Biology 68 (3): 617-621.

Martín, S.M \& A.C. Díaz. 2016. Histology and gametogenesis in Heleobia piscium (Cochliopidae) from the Multiple Use Reserve "Isla Martín García," Buenos Aires, Argentina. PeerJ 4:e2548.

Merlo, M.J., M. Parietti \& J.A. Etchegoin. 2014. Digeneos larvales de Heleobia parchappii y Heleobia australis en ambientes dulceacuícolas y estuariales de la provincia de Buenos Aires (Argentina). Revista Argentina de Parasitología 2: 14-21.

Merlo, M.J, M. Parietti \& J.A. Etchegoin. 2016. LongTerm study of the life cycle of the freshwater snail Heleobia parchappii (Mollusca:Cochliopidae) in a lentic environment in Argentina. Limnetica 29: 49-60.

Merlo, M.J, M. Parietti \& J.A. Etchegoin. 2017. Stunting of the penis in Heleobia parchappii (Mollusca: Cochliopidae) and its relationship with parasitism. Diseases of Aquatic Organisms, 123: 81-85.

Minchella, D.J. 1985. Host life-history variation in response to parasitism. Parasitology 90: 205-216.

Minchella, D.J., B.K. Leathers, K.M. Brown \& J.N. Mcnair. 1985 . Host and parasite counter adaptations: an example from a freshwater snail. American Naturalist 126: 843-854.

Olmos, V. \& M. George-Nascimento. 1997. El gremio de larvas de Digenea en el caracol del sur de Chile Chilina dombeyana: ¿Qué indica la tasa metabólica de los hospedadores parasitados? Revista Chilena de Historia Natural 70: 109-118.

Ostrowski de Núñez, M. 1978. Fauna de agua dulce de la República Argentina, VII: cercarias de la familia Schistosomatidae (Trematoda: Digenea). Revista Museo Argentino de Ciencias Naturales Bernardino Rivadavia, Parasitología 2(3): 65-76.

Ostrowski de Núñez, M. 1992. Trematoda. Familias Strigeidae, Diplostomidae, Clinostomidae, Schistosomatidae, Spirorchiidae y Bucephalidae. In: CASTELLANOS ZA DE. (ed ). Fauna de agua dulce de la República Argentina PROFADU (CONICET) 9 (1): 5-55

Paschoal, S. \& S.B. AMATO. 1996. Eurytrema coelomaticum (Giard et Billet)(Digenea, Dicrocoeliidae) em Bradybaena similaris (Férussac)(Gastropoda, Xanthonychidae): alteracoes nos dapósitos de calcio e na funcao reprodutiva do primeiro hospedeiro intermediário. Revista Brasileira de Zoología 13: 411-418.

Ríos, D. 2009. Espacio urbano y riesgo de desastres: la expansión de las urbanizaciones cerradas sobre áreas inundables de Tigre (Argentina). Ambiente \& Sociedade 12: 99-114.

Ríos, D \& P. Pírez. 2008. Urbanizaciones cerradas en áreas inundables del municipio de Tigre: ¿producción de espacio urbano de alta calidad ambiental? Revista Eure 34: 99-119.

Rumi, A, D.E. Gutiérrez Gregoric, V. Núñez \& D.A. Darrigran. 2008. Malacología latinoamericana. Moluscos de agua dulce de Argentina. Revista Biología Tropical 56: 77-111.

Rumi, A. \& V. Núñez. 2013. Gasterópodos continentales 
de importancia sanitaria en el noreste argentino. In: SALOMON OE AND RUMI A (Eds), Moluscos de interés sanitario en la Argentina. Editorial INMeT, Ciudad Autónoma de Buenos Aires, Argentina, p. 7-39.

Sivajothi, S. \& B. Sudhakara Reddy. 2018. A review on parasitic castration in veterinary parasitology. Journal of Entomology and Zoology Studies, 6(1): 635-639.

Sorensen, R.F. \& D.J. Minchella. 2001. Snail-trematode life history interactions: past trends and future directions. Parasitology 123(7): 3-18.

Sousa, W.P. 1990. Spatial scale and the processes structuring a guild of larval trematode parasites. In: ESCH GW ET AL. (Eds), Parasite communities: Patterns and processes. Chapman and Hall, London, U.K, p. 41-67.

Szidat, L. 1958. Investigaciones sobre Cercaria chascomusi n. sp. Agente causal de una nueva enfermedad humana en la Argentina: "la dermatitis de los bañistas de la laguna Chascomús”. Boletín del Mu- seo Argentino de Ciencias Naturales Bernardino Rivadavia 18: 13.

Théron, A. \& C.Gérard. 1994. Development of accessory sexual organs in Biomphalaria glabrata (Planorbidae) in relation to timing of infection by Schistosoma mansoni: consequences for energy utilization patterns by the parasite. Journal of Molluscan Studies 60: 25-31.

Valdovinos, C. \& C. Balboa. 2008. Cercarial dermatitis and lake eutrophication in south-central Chile. Epidemiology Infection 136, 391-394

Zimmermann, M.R, K.E. Luth \& G.W. Esch. 2014. Microhabitat differences surrounding a pond affects the distribution of trematode parasites among a pulmonate snail community. Helmintohologia, 51,4:301-308.

Zimmermann, M.R., K.E. Luth \& G.W. Esch. 2016. Tranmission pattern differences of miracidia and cercariae larval stages of digenetic trematode parasites. Acta parasitologica 61, 680-688.

Doi: 10.22179/REVMACN.21.609

Recibido: 5-XI-2018

Aceptado: 2-VI-2019 